\title{
The use of active learning strategies in healthcare colleges in the Middle East
}

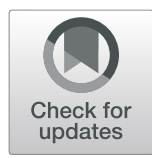

\author{
Yazed AlRuthia ${ }^{1 *} \mathbb{D}$, Solaiman Alhawas ${ }^{2}$, Faris Alodaibi ${ }^{3}$, Lama Almutairi ${ }^{4}$, Reem Algasem² ${ }^{2}$ Haitham K. Alrabiah ${ }^{5}$,
} Ibrahim Sales ${ }^{1}$, Hana Alsobayel ${ }^{3}$ and Yazeed Ghawaa ${ }^{1}$

\begin{abstract}
Background: Multiple studies have explored the use of active learning strategies among faculty members in different healthcare colleges worldwide, however, very few have described the use of these strategies in the Middle East. The aim of this study was to evaluate the extent of the implementation of active learning and its various techniques across different fields of healthcare education in various countries in the Middle East.

Methods: A Web-based questionnaire was developed to obtain information on the use of active learning methods. This survey was disseminated among faculty members in healthcare colleges in 17 Middle Eastern countries.

Results: Out of 22,734 online invitations that were sent to faculty members in different healthcare colleges, 2085 (9.17\%) accepted the invitations, however, only 722 (34.63\%) of those who agreed to participate filled out the questionnaire. Eighty-seven percent of the responders utilized at least one technique of active learning. Active learning was used more frequently by female responders. For example, $54.30 \%$ of the female responders reported using learning by teaching as one of their teaching methods compared to $41.30 \%$ of their male counterparts $(p=0.0005)$. The various forms of active learning were used at similar levels in both public and private healthcare colleges. Only minor differences were seen among different age groups or academic positions of the responders, but significant variabilities were noted among the several fields of healthcare education. For example, $61.54 \%$ of responders from the nursing faculty reported using reaction to videos as one of their teaching methods compared to $31.11 \%$ of their counterparts in the faculty of dentistry $(p=0.0021)$. The most frequently reported obstacles interfering with the effectuation of active learning include the lack of technical support and time constraints.
\end{abstract}

Conclusions: Although some barriers to the implementation of active learning exist, it is extensively used by faculty members in healthcare colleges in the Middle East.

Keywords: Active learning, Healthcare education, Middle East

\section{Background}

Recent decades witnessed an increase in the efforts to enhance the traditional methods of teaching, including those utilized in institutions of higher education [1, 2]. This search for novel approaches embraced the active learning technique, which comprises instructional methods that compel the student to become thoroughly engaged in the process of gaining knowledge [3, 4]. Unlike the traditional learning, active learning requires the students to take part in activities that involve higher-order thinking $[4,5]$. It

\footnotetext{
* Correspondence: yazeed@ksu.edu.sa

'Department of Clinical Pharmacy, College of Pharmacy, King Saud

University, P.O. Box 2454, Riyadh 11451, Saudi Arabia

Full list of author information is available at the end of the article
}

shifts the control of the process from the teacher to the students and helps students to take responsibility for their own learning [4]. Evidence on the higher efficiency of active learning over the conventional methods is growing [6-8]. A meta-analysis of data obtained from 225 studies revealed that active learning in undergraduate science courses resulted in a $6 \%$ improvement in student performance on exams and that students participating in courses taught by traditional lectures were $50 \%$ more likely to fail [9]. Given this shift in teaching methods, the new standards of the Accreditation Council for Pharmacy Education (ACPE) recommend the inclusion of the principles of active learning in the curricula to promote student learning and achievement of

(c) The Author(s). 2019 Open Access This article is distributed under the terms of the Creative Commons Attribution 4.0 International License (http://creativecommons.org/licenses/by/4.0/), which permits unrestricted use, distribution, and 
professional abilities, such as critical thinking, communication, and self-learning [5, 10, 11].

A variety of active learning techniques have been described in the literature. The most common classroom-based active learning strategies include cooperative learning, problem-based learning, case-based learning, and ability-based education [12-16]. Although active learning has gained enthusiastic supporters among innovation-embracing faculty, several faculty members regard it as a transient fashion [3]. Additionally, many obstacles negatively affect the implementation of active learning techniques. They include an inadequate time to cover the content of a course, excessive pre-class preparation requirements, difficulties in implementation in a large-class setting, lack of resources to support active learning, perception by some faculty that they are good lecturers, and avoidance of risk associated with switching to a different teaching paradigm [17].

Several studies have demonstrated the acceptability and the increasing use of active learning principles in the education of healthcare professionals in the Middle East $[18,19]$. Recently, six international Doctor of Pharmacy degree programs were certified by the ACPE, and four of them were in the Middle East [20]. That decision indicates that these programs are aligning their curricula with the ACPE standards. Numerous studies in the field of healthcare education, performed specifically in the Middle East, have evaluated the efficiency of active learning in comparison with traditional lecturing $[14,15$, 21]. However, the extent of utilization of active learning methods across different healthcare specialties in the Middle East is yet to be explored. Thus, the objective of the present study was to assess the use of active learning methods in healthcare programs in various Middle Eastern countries as well as to explore the difficulties that might be hindering the adoption of these teaching strategies among faculty members in different healthcare programs in this region.

\section{Methods}

A new Web-based questionnaire was developed to obtain information regarding the most commonly employed active learning methods, potential difficulties in their implementation, the sociodemographic characteristics and academic positions of the faculty members. Eight questions were asked: 1. Age; 2. Gender; 3. College (medicine, pharmacy, dentistry, applied medical sciences, nursing, public health, other); 4. Academic rank (teaching assistant, lecturer, assistant professor, associate professor, professor); 5. Country; 6. Source of funding for the academic institution (public, private); 7. Active learning methods (class discussion, think-pair-share, learning cell, collaborative learning, student debate, reaction to videos, small group discussion, class game, learning by teaching, gallery walk, case studies and problem-based learning, flipped classroom, gamification, and computerbased learning); and 8. Reasons for not adopting active learning strategies (lack of technical support, lack of administrative support, no appreciation, time constraint, and disinterest). Multiple answers were possible for questions 7 and 8 [Additional file 1].

The face and content validity of the questionnaire were independently checked by three faculty members from the colleges of applied medical sciences, medicine, and pharmacy. This survey was disseminated among various healthcare colleges in the Middle East. These institutions were identified by visiting the websites of the ministries of education or higher education of each country, and by manually searching for active websites of healthcare colleges in 17 Middle Eastern countries. Thereafter, a list of email addresses for faculty members in different healthcare colleges in each of the 17 Middle Eastern countries (Saudi Arabia, Qatar, Egypt, Israel, Iraq, Turkey, Bahrain, United Arab Emirates, Sudan, Oman, Jordan, Palestine, Yemen, Iran, Lebanon, Cyprus, and Tunisia) was prepared. The corresponding author was then asked to email a cover letter to all identified email addresses describing the purpose of this online survey as well as an invitation to participate in the study by filling out an online questionnaire that will be sent automatically should they agree to participate in the study.

The reliability of the questionnaire was assessed using the Cronbach's alpha method [22]; the test returned an alpha value of 0.70 indicating a satisfactory level of reliability. The sociodemographic and academic institutions' characteristics of the responders (age, gender, college, academic rank, country, and source of institution funding) were presented as frequencies and percentages. Chi-square and Fisher's exact tests were performed, as appropriate, to compare the proportions of responders who used each of the listed active learning methods (class discussion, think-pair-share, learning cell, collaborative learning, student debate, reaction to videos, small group discussion, class game, learning by teaching, gallery walk, case studies and problem-based learning, flipped classroom, gamification, and computer-based learning) across gender, age groups, academic ranks, and healthcare colleges. Also, Chi-square test was used to compare the proportions of responders who reported each of the listed reasons for not adopting active learning strategies (lack of technical support, lack of administrative support, no appreciation, time constraint, and disinterest) across gender and source of funding for the academic institution. Statistical analysis was performed using Statistical Analysis Software version 9.2 (SAS Institute, Inc., Cary, NC, USA). $p$ values of less than 0.05 were considered to be statistically significant. 


\section{Results}

The search for contact information of faculty members in healthcare educational institutions yielded valid email addresses of 22,734 academicians, of which 722 responded to the provided questionnaire (Fig. 1). Most of the responders were 44 years of age or younger (67\%), worked in pharmacy or medical colleges (55\%), hold positions of lecturer or assistant professor (63\%), and were employed in public institutions (85\%). Responses were obtained from academicians representing all 17 Middle Eastern countries, although a disproportionality in the number of replies between different countries was noted (Table 1).

The most frequently utilized forms of active learning were by far discussions (Table 2). Class discussion was reported by $87 \%$ of the faculty, and small group discussion by $63 \%$. The least used approaches were gallery walk $(2.1 \%)$, gamification $(2.8 \%)$ and learning cell (7.1\%). With two exceptions (learning cell and student debate), a higher fraction of female responders was engaged in each type of activity, and in most cases, this difference reached statistical significance $(p<0.05)$. For example, the percentage of female responders who reported using class games in the curriculum was three times higher than their male counterparts $(20.18 \%$ vs. $6.75 \% ; p<0.0001$ ). Moreover, the percentage of female responders who reported using reaction to videos as part of their courses was 1.5 times higher than their male counterparts $(50.15 \%$ vs. $34.03 \% ; p<0.0001)$.Of note, the various forms of active learning were employed at a similar frequency in public and private schools $(p \geq 0.05)$ (Fig. 2).

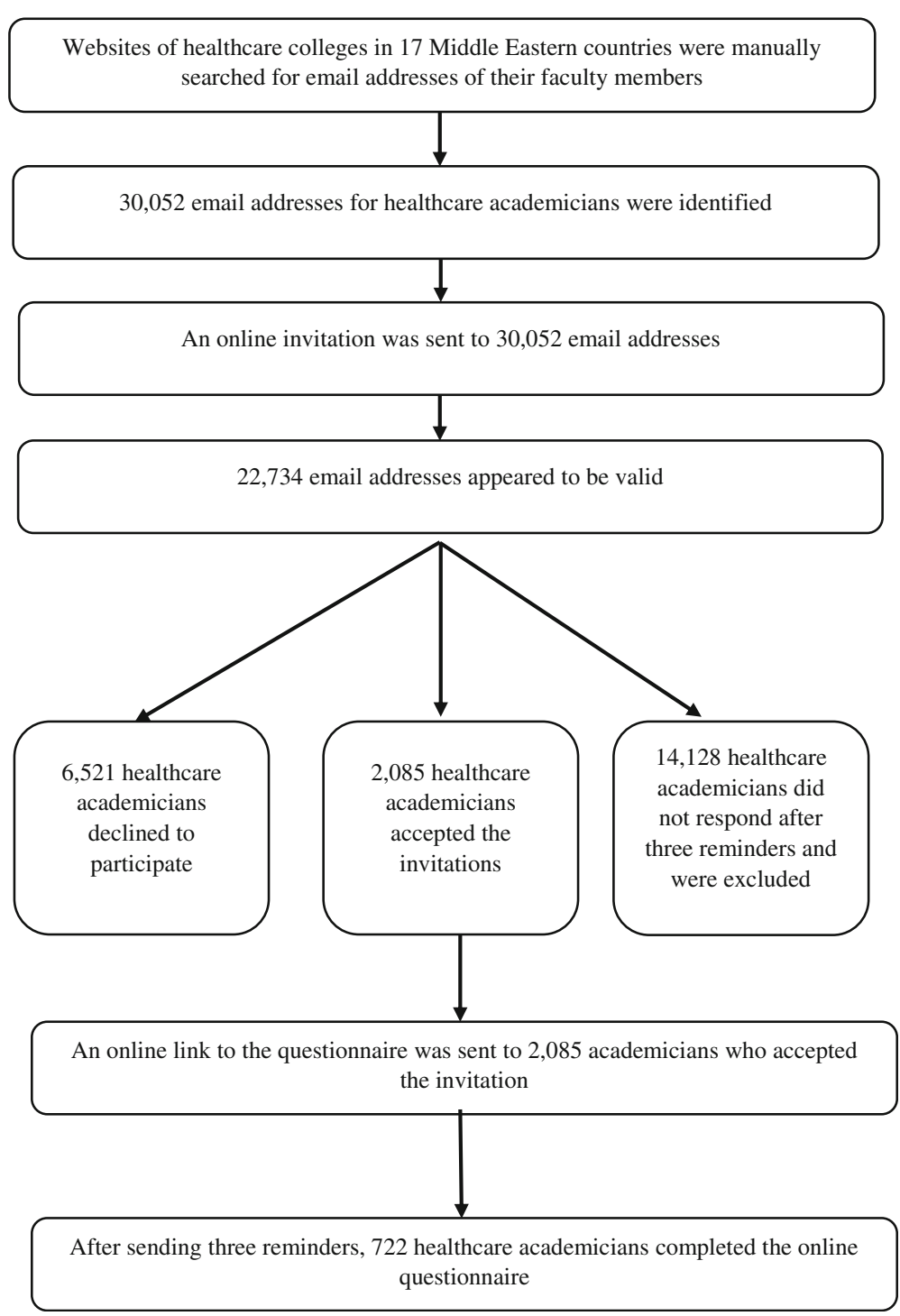

Fig. 1 The flow diagram of recruitment of study responders 
Table 1 Sociodemographic characteristics of the responders

\begin{tabular}{|c|c|}
\hline Characteristic & Number of responders $n(\%)$ \\
\hline \multicolumn{2}{|l|}{ Gender } \\
\hline Male & $385(53.32)$ \\
\hline Female & $337(46.68)$ \\
\hline \multicolumn{2}{|l|}{ Age (years) } \\
\hline $20-24$ & $4(0.55)$ \\
\hline $25-34$ & 205 (28.39) \\
\hline $35-44$ & $274(37.95)$ \\
\hline $45-54$ & $141(19.53)$ \\
\hline $55-64$ & 79 (10.94) \\
\hline $65-74$ & $17(2.35)$ \\
\hline $75-84$ & $2(0.28)$ \\
\hline \multicolumn{2}{|l|}{ College } \\
\hline Dentistry & $90(12.47)$ \\
\hline Applied medical sciences & $138(19.11)$ \\
\hline School of public health & $15(2.08)$ \\
\hline Pharmacy & $202(27.98)$ \\
\hline Medicine & $195(27.01)$ \\
\hline Nursing & $78(10.8)$ \\
\hline Other ${ }^{a}$ & $4(0.55)$ \\
\hline \multicolumn{2}{|l|}{ Rank } \\
\hline Teaching assistant & $93(12.88)$ \\
\hline Lecturer & 231 (31.99) \\
\hline Assistant professor & $224(31.02)$ \\
\hline Associate professor & $86(11.91)$ \\
\hline Professor & $88(12.19)$ \\
\hline \multicolumn{2}{|l|}{ Country } \\
\hline Kingdom of Saudi Arabia & $410(56.79)$ \\
\hline Qatar & $4(1.25)$ \\
\hline Egypt & $143(19.81)$ \\
\hline Israel & $23(3.19)$ \\
\hline Iraq & $57(7.89)$ \\
\hline Turkey & $18(2.49)$ \\
\hline Bahrain & $12(1.66)$ \\
\hline United Arab Emirates & $13(1.8)$ \\
\hline Sudan & $6(0.83)$ \\
\hline Oman & $13(1.8)$ \\
\hline Jordan & $6(0.83)$ \\
\hline Palestine & $5(0.69)$ \\
\hline Other ${ }^{b}$ & $7(0.97)$ \\
\hline \multicolumn{2}{|l|}{ Institution Funding } \\
\hline Public & $617(85.46)$ \\
\hline Private & $105(14.54)$ \\
\hline
\end{tabular}

${ }^{a}$ Child development, preparatory health, student, university-affiliated teaching hospital

bYemen, Iran, Cyprus, Lebanon, Tunisia
Some differences in the incidence of implementation of active learning were seen among faculty members of different ages (Table 3). For example, the percentage of responders between 25 to 34 years of age who reported applying collaborative learning was $31.22 \%$ compared to 46.18 and $52.94 \%$ among those between 45 to 54 and 65 to 74 years of age, respectively, $(p=0.0054)$. Furthermore, responders between 25 to 34 years of age reported using reaction to videos more often than their counterparts between 65 to 74 years of age $(45.85 \%$ vs. $29.41 \%$; $p=0.0178)$. On the other hand, responders aged between 65 to 74 years reported using case studies and problem based learning, flipped classroom, and gamification more often than their counterparts in other age groups $(p<0.05)$.

Similar trends were seen when the academic rank of responders was considered (Table 4). The frequency of use of eight types of activities exhibited variability with the type of appointment. For example, the percentage of responders who reported using class discussion was the highest among associate professors (93.02\%) compared to 80.68 and $90.18 \%$ among professors and assistant professors, respectively, $(p=0.0027)$. On the other hand, professors reported the highest rate of using student debate (36.36\%) compared to 27.91 and $29.91 \%$ among associate professors and assistant professors, respectively, $(p=0.0003)$. However, assistant professors reported the highest rate of using collaborative learning $(46.88 \%)$, reaction to videos (45.98\%), small group discussion (66.96\%), class game (18.30\%), and flipped classroom (12.79\%) compared to their counterparts from other academic ranks $(p<0.05)$.

Nine of 15 types of active learning activities showed significant variability among schools in different fields of healthcare education (Table 5). Responders from public health schools reported the highest utilization rates of collaborative learning (80\%), class game $(46.67 \%)$, buzz group and brainstorming (46.67\%), and flipped classroom (33.33\%) compared to their counterparts from other healthcare colleges $(p<0.05)$. On the other hand, responders from nursing schools reported the highest utilization rates of think-pair-share (33.33\%) and reaction to videos $(61.54 \%)$ compared to their counterparts from other healthcare colleges $(p<0.05)$. However, responders from the colleges of applied medical sciences, dentistry, and medicine reported the highest utilization rates of class discussion (93.48\%), case studies and problem based learning (63.33\%), and small group discussion (69.23\%), respectively, compared to their counterparts from other healthcare colleges $(p<0.05)$.

The most frequently claimed reasons for not adopting active learning strategies was the lack of technical support and time constraints (Table 6). There was no significant difference between genders in the evaluation of 
Table 2 The use of active learning methods among health care academicians in the Middle East

\begin{tabular}{|c|c|c|c|c|}
\hline \multirow[t]{3}{*}{ Active learning method } & \multirow{3}{*}{$\begin{array}{l}\text { Responder } \\
\mathrm{n}(\%)\end{array}$} & \multicolumn{2}{|l|}{ Gender } & \multirow[t]{3}{*}{$p$-value } \\
\hline & & \multirow{2}{*}{$\begin{array}{l}\text { Male } \\
\text { n (\%) }\end{array}$} & \multirow{2}{*}{$\begin{array}{l}\text { Female } \\
\mathrm{n}(\%)\end{array}$} & \\
\hline & & & & \\
\hline Class discussion & $630(87.26)$ & $323(83.90)$ & $307(91.10)$ & $0.0038^{*}$ \\
\hline Think-pair-share & $149(20.64)$ & $68(17.66)$ & $81(24.04)$ & $0.0348^{*}$ \\
\hline Learning cell & $51(7.06)$ & $31(8.05)$ & $20(5.93)$ & 0.2680 \\
\hline Collaborative learning & $307(42.52)$ & $150(38.96)$ & $157(46.59)$ & $0.0386^{*}$ \\
\hline Student debate & $196(27.15)$ & $109(28.31)$ & $87(25.82)$ & 0.4519 \\
\hline Reaction to videos & $300(41.55)$ & $131(34.03)$ & $169(50.15)$ & $<0.0001^{*}$ \\
\hline Small group discussion & $455(63.02)$ & $229(59.48)$ & $226(67.06)$ & $0.0353^{*}$ \\
\hline Class game & $94(13.02)$ & $26(6.75)$ & $68(20.18)$ & $<0.0001^{*}$ \\
\hline Learning by teaching & $342(47.37)$ & $159(41.30)$ & $183(54.30)$ & $0.0005^{*}$ \\
\hline Gallery walk & $15(2.08)$ & $6(1.56)$ & $9(2.67)$ & 0.2959 \\
\hline Buzz group and brainstorming & $193(26.73)$ & $90(23.38)$ & $103(30.56)$ & $0.0295^{*}$ \\
\hline Case studies and problem based learning & $382(52.91)$ & $186(48.31)$ & $196(58.16)$ & $0.0082^{*}$ \\
\hline Flipped classroom & $73(10.11)$ & $33(8.57)$ & $40(11.87)$ & 0.1425 \\
\hline Gamification & $20(2.77)$ & $7(1.82)$ & $13(3.86)$ & 0.0957 \\
\hline Computer-based learning & $255(35.32)$ & $124(32.21)$ & $131(38.87)$ & 0.0616 \\
\hline
\end{tabular}

"Indicates significant difference between males and females $(p<0.05)$

these obstacles, with the only exception of women citing the existence of time constraints more often than men $(51.93 \%$ vs. $35.84 \% ; p<0.0001)$. Conversely, several differences were identified when public and private colleges were compared. The faculty in public schools pointed more often than their counterparts in private schools to the lack of technical support $(41.17 \%$ vs. $25.25 \%$; $p=$ $0.0057)$, lack of administrative support $(24.47 \%$ vs. $12.12 \% ; p=0.023)$, and the presence of time constraints (45.22\% vs. $30.30 \% ; p=0.0107)$.

\section{Discussion}

The current study represents, to the best of our knowledge, the first effort to explore the prevalence of utilization of active learning strategies in the Middle East. The responders were from different Middle Eastern countries and reflected most healthcare specialties. The results of the survey indicated that the active learning methods are prominently applied in this part of the world. Class and small-group discussions were the most commonly used methods by responders of both sexes

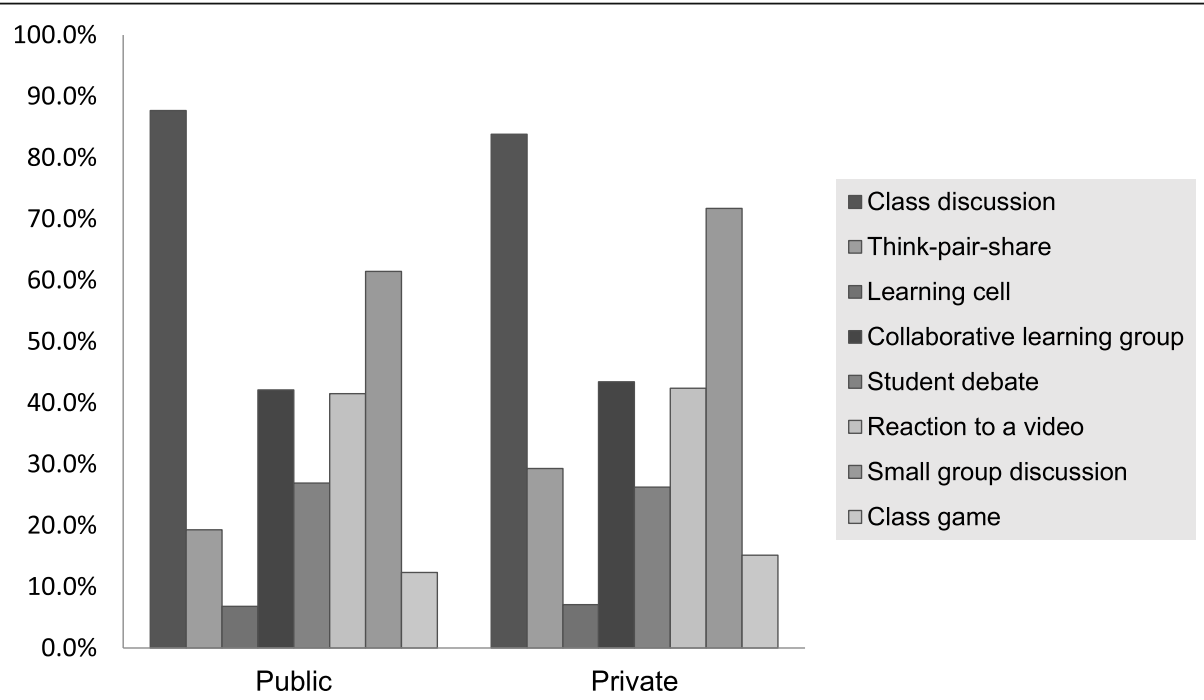

Fig. 2 The use of different active learning strategies based on the institution's funding 
Table 3 The use of active learning methods among different age groups of healthcare academicians in the Middle East

\begin{tabular}{|c|c|c|c|c|c|c|c|c|}
\hline \multirow[t]{2}{*}{ Active learning method } & \multicolumn{7}{|c|}{ Age group (years) } & \multirow[t]{2}{*}{$p$-value } \\
\hline & $\begin{array}{l}20-24(4 \\
\text { resp.) n (\%) }\end{array}$ & $\begin{array}{l}25-34(205 \\
\text { resp.) n (\%) }\end{array}$ & $\begin{array}{l}35-44(274 \\
\text { resp.) n (\%) }\end{array}$ & $\begin{array}{l}45-54(141 \\
\text { resp.) } n(\%)\end{array}$ & $\begin{array}{l}55-64(79 \\
\text { resp.) n (\%) }\end{array}$ & $\begin{array}{l}65-74(17 \\
\text { resp.) } n(\%)\end{array}$ & $\begin{array}{l}75-84(2 \\
\text { resp.) n (\%) }\end{array}$ & \\
\hline Class discussion & $3(75.00)$ & $177(86.34)$ & $247(90.15)$ & $125(88.65)$ & $63(79.75)$ & $13(76.47)$ & $2(100)$ & 0.1693 \\
\hline Think-pair-share & $2(50.00)$ & $31(15.12)$ & $64(23.36)$ & $32(22.70)$ & $16(20.25)$ & $4(23.53)$ & $0(0.00)$ & 0.2288 \\
\hline Learning cell & $1(25.00)$ & $7(3.41)$ & $20(7.30)$ & $16(11.35)$ & $5(6.33)$ & $2(11.76)$ & $0(0.00)$ & 0.0924 \\
\hline Collaborative learning & $3(75.00)$ & $64(31.22)$ & $129(47.08)$ & $66(46.81)$ & $36(45.57)$ & $9(52.94)$ & $0(0.00)$ & $0.0054^{*}$ \\
\hline Student debate & $1(25.00)$ & $42(20.49)$ & $79(28.83)$ & $44(31.21)$ & $25(31.65)$ & $5(29.41)$ & $0(0.00)$ & 0.2553 \\
\hline Reaction to videos & $3(75.00)$ & $94(45.85)$ & $125(45.62)$ & $51(36.17)$ & $21(26.58)$ & $5(29.41)$ & $1(50.00)$ & $0.0178^{*}$ \\
\hline Small group discussion & $4(100.00)$ & $112(54.63)$ & $182(66.42)$ & $92(65.25)$ & $52(65.82)$ & $11(64.71)$ & $2(100.00)$ & 0.0701 \\
\hline Class game & $0(0.00)$ & $25(12.20)$ & $44(16.06)$ & $16(11.35)$ & $6(7.59)$ & $3(17.65)$ & $0(0.00)$ & 0.4257 \\
\hline Learning by teaching & $4(100.00)$ & $91(44.39)$ & $127(46.35)$ & $74(52.48)$ & $39(49.37)$ & $7(41.18)$ & $0(0.00)$ & 0.1761 \\
\hline Gallery walk & $0(0.00)$ & $5(2.44)$ & $4(1.46)$ & $4(2.84)$ & $1(1.27)$ & $1(5.88)$ & $0(0.00)$ & 0.8527 \\
\hline Buzz group and brainstorming & $2(50.00)$ & $38(18.54)$ & $79(28.83)$ & $46(32.62)$ & $22(27.85)$ & $6(35.29)$ & $0(0.00)$ & $0.0486^{*}$ \\
\hline $\begin{array}{l}\text { Case studies and problem } \\
\text { based learning }\end{array}$ & $2(50.00)$ & $92(44.88)$ & $162(59.12)$ & $67(47.52)$ & $48(60.76)$ & $10(58.82)$ & $1(50.00)$ & $0.0369^{*}$ \\
\hline Flipped classroom & $0(0.00)$ & $10(4.88)$ & $28(10.22)$ & $19(13.48)$ & 12(15.19) & $4(23.53)$ & $0(0.00)$ & $0.0273^{*}$ \\
\hline Gamification & $0(0.00)$ & $6(2.93)$ & $6(2.19)$ & $4(2.83)$ & $1(1.27)$ & $3(17.65)$ & $0(0.00)$ & $0.0190^{*}$ \\
\hline Computer-based learning & $1(25.00)$ & $64(31.22)$ & $114(41.61)$ & $44(31.21)$ & $28(35.44)$ & $3(17.65)$ & $1(50.00)$ & 0.1250 \\
\hline
\end{tabular}

resp. responders, N/A not applicable

Indicates significant difference among the age groups $(p<0.05)$

Table 4 The use of active learning methods across the academic ranks in healthcare colleges in the Middle East

\begin{tabular}{|c|c|c|c|c|c|c|}
\hline \multirow[t]{2}{*}{ Active learning method } & \multicolumn{5}{|l|}{ Academic rank } & \multirow[t]{2}{*}{$p$-value } \\
\hline & $\begin{array}{l}\text { Teaching assistant } \\
\text { (93 resp.) n (\%) }\end{array}$ & $\begin{array}{l}\text { Lecturer (231 } \\
\text { resp.) n (\%) }\end{array}$ & $\begin{array}{l}\text { Assistant professor } \\
\text { (224 resp.) n (\%) }\end{array}$ & $\begin{array}{l}\text { Associate professor } \\
\text { (86 resp.) n (\%) }\end{array}$ & $\begin{array}{l}\text { Professor ( } 88 \\
\text { resp.) n (\%) }\end{array}$ & \\
\hline Class discussion & $72(77.42)$ & $205(88.74)$ & $202(90.18)$ & $80(93.02)$ & $71(80.68)$ & $0.0027^{*}$ \\
\hline Think-pair-share & $11(11.83)$ & $54(23.38)$ & $53(23.66)$ & $17(19.77)$ & 14(15.91) & 0.0932 \\
\hline Learning cell & $6(6.45)$ & $9(3.90)$ & $21(9.38)$ & $6(6.98)$ & $9(10.23)$ & 0.1498 \\
\hline Collaborative learning & $23(24.73)$ & $104(45.02)$ & $105(46.88)$ & $36(41.86)$ & $39(44.32)$ & $0.0059^{*}$ \\
\hline Student debate & $8(8.60)$ & 65 (28.14) & $67(29.91)$ & $24(27.91)$ & $32(36.36)$ & $0.0003^{*}$ \\
\hline Reaction to videos & $36(38.71)$ & $108(45.75)$ & $103(45.98)$ & $36(41.86)$ & $17(19.32)$ & $0.0002^{*}$ \\
\hline Small group discussion & $44(47.31)$ & $151(65.37)$ & $150(66.96)$ & $52(60.47)$ & $58(65.91)$ & $0.0143^{*}$ \\
\hline Class game & $9(9.68)$ & $32(13.85)$ & $41(18.30)$ & $5(5.81)$ & $7(7.95)$ & $0.0139^{*}$ \\
\hline Learning by teaching & $41(44.09)$ & 103(44.59) & $111(49.55)$ & $46(53.49)$ & $41(46.59)$ & 0.5815 \\
\hline Gallery walk & $2(2.15)$ & $5(2.16)$ & $5(2.23)$ & $0(0)$ & $3(3.41)$ & 0.6217 \\
\hline Buzz group and brainstorming & $18(19.35)$ & $61(26.41)$ & $67(29.91)$ & $18(20.93)$ & 29(32.95) & 0.1375 \\
\hline $\begin{array}{l}\text { Case studies and problem } \\
\text { based learning }\end{array}$ & $42(45.16)$ & $121(52.38)$ & $130(58.04)$ & $39(45.35)$ & $50(56.82)$ & 0.1286 \\
\hline Flipped classroom & $1(1.08)$ & $21(9.09)$ & $31(13.84)$ & $11(12.79)$ & $9(10.23)$ & $0.0127^{*}$ \\
\hline Gamification & $4(4.30)$ & $2(0.87)$ & $9(4.02)$ & $1(1.16)$ & $4(4.55)$ & 0.1323 \\
\hline Computer-based learning & $22(23.66)$ & $88(38.10)$ & $91(40.63)$ & $22(25.58)$ & $32(36.36)$ & $0.0129^{*}$ \\
\hline
\end{tabular}


Table 5 The use of active learning methods in various types of healthcare colleges in the Middle East

\begin{tabular}{|c|c|c|c|c|c|c|c|}
\hline \multirow[t]{2}{*}{ Active learning method } & \multicolumn{6}{|c|}{ Type of healthcare college } & \multirow[t]{2}{*}{$p$-value } \\
\hline & $\begin{array}{l}\text { Pharmacy (202 } \\
\text { resp.) n (\%) }\end{array}$ & $\begin{array}{l}\text { Medicine (195 } \\
\text { resp.) n (\%) }\end{array}$ & $\begin{array}{l}\text { Dentistry ( } 90 \\
\text { resp.) n (\%) }\end{array}$ & $\begin{array}{l}\text { Nursing (78 } \\
\text { resp.) n (\%) }\end{array}$ & $\begin{array}{l}\text { Applied medical } \\
\text { sciences (138 resp.) n (\%) }\end{array}$ & $\begin{array}{l}\text { Public health } \\
\text { (15 resp.) } n(\%)\end{array}$ & \\
\hline Class discussion & $177(87.62)$ & 162(83.08) & 78(86.67) & $70(89.74)$ & $129(93.48)$ & $12(80.00)$ & $0.0290^{*}$ \\
\hline Think-pair-share & 37 (18.32) & $37(18.97)$ & 13(14.44) & $26(33.33)$ & $30(21.74)$ & $4(26.67)$ & $0.0383^{*}$ \\
\hline Learning cell & $13(6.44)$ & $11(5.64)$ & $5(5.56)$ & $6(7.69)$ & $14(10.14)$ & $1(0.67)$ & 0.5386 \\
\hline Collaborative learning & 75 (37.13) & 75 (38.46) & $34(37.78)$ & $34(55.13)$ & $67(48.55)$ & $12(80.00)$ & $0.0020^{*}$ \\
\hline Student debate & $57(28.22)$ & $44(22.56)$ & $21(23.33)$ & 23(29.49) & $46(33.33)$ & $4(26.67)$ & 0.4521 \\
\hline Reaction to videos & $82(40.59)$ & $71(36.41)$ & $28(31.11)$ & $48(61.54)$ & $63(45.65)$ & $7(46.67)$ & $0.0021^{*}$ \\
\hline Small group discussion & 115(56.93) & 135(69.23) & $59(65.56)$ & $49(62.82)$ & $90(65.22)$ & $6(40.00)$ & $0.0452^{*}$ \\
\hline Class game & $21(10.40)$ & $15(7.69)$ & $10(11.11)$ & $16(20.51)$ & $24(17.39)$ & $7(46.67)$ & $<0.0001$ \\
\hline Learning by teaching & $100(49.50)$ & $90(46.15)$ & $32(35.56)$ & $44(56.41)$ & $66(47.83)$ & $9(60.00)$ & 0.1309 \\
\hline Gallery walk & $5(2.48)$ & $3(1.54)$ & $0(0)$ & $5(6.41)$ & $2(1.45)$ & $0(0.00)$ & 0.1160 \\
\hline Buzz group and brainstorming & $41(20.30)$ & $53(27.18)$ & $14(15.56)$ & $35(44.87)$ & $42(30.43)$ & $7(46.67)$ & $0.0001^{*}$ \\
\hline $\begin{array}{l}\text { Case studies and problem } \\
\text { based learning }\end{array}$ & $83(41.09)$ & $111(56.92)$ & $57(63.33)$ & $43(55.13)$ & $79(57.25)$ & $7(46.67)$ & $0.0063^{*}$ \\
\hline Flipped classroom & $12(5.94)$ & $28(14.36)$ & $4(4.44)$ & $8(10.26)$ & $16(11.59)$ & $5(33.33)$ & $0.0022^{*}$ \\
\hline Gamification & $8(3.96)$ & $4(2.05)$ & $0(0.00)$ & $4(5.13)$ & $4(2.90)$ & $0(0.00)$ & 0.4054 \\
\hline Computer-based learning & $66(32.67)$ & $61(31.28)$ & $33(36.67)$ & $30(38.46)$ & $54(39.13)$ & $8(53.33)$ & 0.2249 \\
\hline
\end{tabular}

resp. responders

*Indicates significant difference between different types of colleges $(p<0.05)$

and of all ages and academic ranks. However, detailed analysis revealed the presence of several substantial differences in how the various techniques are used in the healthcare education system in the Middle East. The major obstacles in the implementation of active learning were identified as well.

It does not come as a surprise that the most frequently utilized forms of active learning were class and small group discussions. Discussion as a form of gaining knowledge was practiced by Socrates in ancient Greece [23], long before the concept of active learning was formally introduced [24-26]. Moreover, this method of active learning does not require any a priori preparation. In fact, approaches requiring significant effort to develop, such as gallery walk or gamification were used by less than $3 \%$ of the faculty.

One of the most striking findings of the present research was the fact that female responders were more likely to employ active learning strategies than their male counterparts. The reason for this gender disparity is unknown. Switching to novel teaching techniques may be associated with risk-taking, and it has been extensively documented in a number of observational and experimental studies that women are characterized by a

Table 6 Reasons for not adopting active learning methods across genders and types of funding in healthcare colleges in the Middle East

\begin{tabular}{|c|c|c|c|c|c|c|c|c|}
\hline \multirow[t]{2}{*}{ Reason } & \multicolumn{4}{|l|}{ Gender } & \multicolumn{4}{|c|}{ Source of funding } \\
\hline & $\begin{array}{l}\text { Both genders } \\
\text { (722 resp.) } \\
\text { n (\%) }\end{array}$ & $\begin{array}{l}\text { Male } \\
\text { (385 resp.) } \\
\text { n (\%) }\end{array}$ & $\begin{array}{l}\text { Female } \\
\text { (337 resp.) } \\
\text { n (\%) }\end{array}$ & $p$-value & $\begin{array}{l}\text { Any source } \\
(716 \text { resp. })^{a} \\
\text { n (\%) }\end{array}$ & $\begin{array}{l}\text { Public } \\
\text { (617 resp.) } \\
\text { n (\%) }\end{array}$ & $\begin{array}{l}\text { Private } \\
\text { (99 resp.) } \\
\text { n (\%) }\end{array}$ & $p$-value \\
\hline Lack of technical support & $280(38.78)$ & $156(40.52)$ & $124(36.80)$ & 0.3055 & $279(38.97)$ & $254(41.17)$ & $25(25.25)$ & $0.0057^{*}$ \\
\hline Lack of administrative support & $164(22.71)$ & $91(23.64$ & $73(21.66)$ & 0.5275 & $163(22.77)$ & $151(24.47)$ & $12(12.12)$ & $0.0230^{*}$ \\
\hline No appreciation & $134(18.56)$ & 69 (17.92) & 65 (19.29) & 0.6377 & $133(18.58)$ & $122(19.77)$ & $11(11.11)$ & 0.1195 \\
\hline Time constraint & $313(43.35)$ & $138(35.84)$ & $175(51.93)$ & $<0.0001^{*}$ & 309 (43.16) & $279(45.22)$ & $30(30.30)$ & $0.0107^{*}$ \\
\hline Disinterest & $110(15.24)$ & $58(15.06)$ & $52(15.43)$ & 0.8916 & $109(15.22)$ & $91(14.75)$ & $18(18.18)$ & 0.6743 \\
\hline $\begin{array}{l}\text { Refrained from answering } \\
\text { the question }\end{array}$ & $34(4.71)$ & $17(4.42)$ & $17(5.04)$ & 0.6906 & $34(4.75)$ & $27(4.38)$ & $7(7.07)$ & 0.4318 \\
\hline
\end{tabular}

resp. responders

"Indicates significant difference between males and females, or public and private schools $(p<0.05)$

${ }^{a} 6$ responders did not provide information regarding the type of funding 
lower propensity to take risks $[27,28]$. One potential explanation for the higher participation of women in providing active learning environment may be offered by results of a study which indicated that women tend to adopt more democratic and participative style in their leadership role than men, who tend to prefer more autocratic and directive style [29]. This trait may prevail over the avoidance of risk associated with the introduction of novel teaching methods, resulting in the observed gender difference. Interestingly, a recent study has shown that female students perceive the utilization of active learning approaches as a factor positively contributing to their academic experience more often than their male counterparts [30].

When the frequency of use of active learning was compared between public and private colleges, it became apparent that the type of institutional funding does not have a large impact on the choice of learning methods used. The only exception noted was with the think-pair-share which was utilized to a greater extent than the student debates in private schools as opposed to public schools. Possible reasons for this difference may include smaller class sizes and lower time constraints in private universities.

Our data did not reveal a robust correlation between the age of healthcare faculty members and the use of active learning methods. If the data from the oldest (7584 years, 2 responders) and the youngest (20-24 years, 4 responders) groups are excluded on the basis of the very low number of responses, the remaining oldest group (65-74 years) had the highest rate of utilization of think-pair-share, learning cell, collaborative learning, class game, gallery walk, buzz group and brainstorming, flipped classroom, and gamification. Thus, the majority (8 of 15) of active learning techniques were used most frequently in this group of seasoned lecturers. This data appears to contradict the notion that the older healthcare faculty members are discouraged from implementing active learning methods by approaching retirement age, or by the self-perception of being a good lecturer after years of teaching [31]. In a European study, younger teachers described old cadre as real obstacles to using active learning methods, claiming that older teachers are cynical, burned out, and do not have the energy to apply new ways of teaching [32]. The current data contradict these sentiments, particularly taking into account that in most European countries faculty must retire at the age of 65 , before even reaching the age of responders in the two oldest groups of the present analysis of Middle Eastern countries.

The reason for these major discrepancies remains to be explained. It may reflect the different attitudes toward older members of the society in various parts of the world [33]. However, the alternative explanation in which old professors who are not interested in active learning might have elected not to participate in this study cannot be excluded.

Among the most frequently cited reasons for not adopting active learning methods was time constraint. This finding is consistent with the previously published data [31]. The current results indicate additionally that the female faculty were $45 \%$ more likely than their male counterparts to indicate time constraint as a barrier to the implementation of active learning. The underlying cause of this gender-dependent perception remains to be identified. Lack of technical and administrative support as well as time constraints were reported more often by responders from public schools; this might be related to a higher level of bureaucracy in public schools. Alternatively, this may reflect a greater effort of private schools to attract students, who are generally more enthusiastic about active learning than traditional teaching [31, 34]. It is noteworthy, however, that in spite of a smaller number of obstacles in private schools, the extent to which active learning was incorporated in the curriculum was comparable to that seen in public schools (Fig. 2).

\section{Study limitations}

Although this study is the first, to the best of our knowledge, to explore the prevalence of active learning methods utilization in different healthcare colleges in the Middle East, it has multiple limitations. First and foremost, the low response rate (722 responses out of 22,734 sent emails) despite three online reminders that were sent asking faculty members in different Middle Eastern healthcare colleges to participate; this can be due to a multitude of factors. These factors can be cultural in which people in the Middle East are not used to fill out online questionnaires; something that was confirmed in a study that was conducted in Saudi Arabia to compare the response rates between Web and telephone surveys, and found a significantly lower response rate for Web survey compared to telephone survey despite the fact that the number of Internet users is significantly higher than the number of telephone landline subscribers [35]. In addition to the cultural factors, Web surveys had traditionally lower response rates compared to telephone, paper, or personal interview surveys mainly due to people's concern with the confidentiality of the provided information as well as the reliability of the sources of Web surveys [36, 37]. We have tried to address these issues by using an institutional email with the name and contact information of the corresponding author as well as by sending a cover letter that described the purpose of the study and invited the addressees to participate prior to emailing them the link to the online questionnaire, which was only sent to those who agreed to participate. Another potential factor that may have 
contributed to the low response rate is the language of the administered online questionnaire [38]. Although the questionnaire was administered in English, which is the language used in teaching in all of the surveyed Middle Eastern healthcare colleges, English is not the native language in any of the surveyed countries. Moreover, the majority of the responders were between 25 to 54 years of age which could be attributable to the low digital literacy level and use of Internet among old faculty members compared to their younger counterparts [39]. In addition, more than $50 \%$ of the responders were from Saudi Arabia, which can be due to the familiarity of the responders with the academic institution in which the questionnaire was developed and sent from as well as the higher rate of Internet utilization compared to most Middle Eastern countries [35]. Furthermore, some Middle Eastern countries such as Syria and Morocco were excluded mainly because of the language barrier where most of their healthcare colleges' curricula are not taught in English. Finally, the use of convenience sampling which was employed due to resource and time constraints is another limitation that may affect the generalizability of the study's findings.

\section{Conclusion}

Middle Eastern healthcare education policymakers should incentivize the use of active learning strategies among their healthcare faculty members to improve the educational outcomes. Although it might be premature to generalize the findings, the accumulated data provide useful insights regarding the various factors that influence the implementation of active learning strategies in the Middle East. Moreover, it indicates the difficulties that hinder the adoption of novel teaching techniques by healthcare academicians in this part of the world.

\section{Additional file}

Additional file 1: The use of active learning strategies in healthcare colleges in the Middle East questionnaire. (DOCX 16 kb)

\section{Abbreviation}

ACPE: Accreditation Council for Pharmacy Education

\section{Acknowledgements}

The authors wish to express their gratitude to the faculty members from the different healthcare colleges and Middle Eastern countries who participated in the study as well as to Dr.Wael Mansy and Mr.Faisal Alyusuf for their help in the data collection. Also, the authors acknowledge financial support from the College of Pharmacy Research Center and the Deanship of Scientific Research, King Saud University (Riyadh, Saudi Arabia).

\section{Funding}

No external funding was provided for the reported research.

\section{Availability of data and materials}

The datasets used and/or analyzed during the current study are available from the corresponding author on reasonable request.

\section{Authors' contributions}

YA, HA, and FA designed the study. YA, SA, FA, YG, and HKA collected data and were responsible for their storage process. YA, RA, LA, and FA performed the statistical analysis. YA, RA, LA, FA, and IS contributed to the interpretation of the results. YA, IS, and SA redacted the first draft of manuscript. All authors participated in the final redaction of manuscript and collectively revised the manuscript. All authors have read and approved the final version of this manuscript.

\section{Ethics approval and consent to participate}

This research has been reviewed and approved by the research ethics committee of the college of pharmacy at King Saud University in Riyadh, Saudi Arabia. The approval ID number is (11/2016). A written consent form was sent via email to all potential participants. The written consent form explained the aim of the study and assured the participants that no personal identifiers will be collected. Once the participants consented to participate they have been directed to the online questionnaire where they can fill out and submit.

\section{Consent for publication}

Not Applicable

\section{Competing interests}

The authors declare that they have no competing interests.

\section{Publisher's Note}

Springer Nature remains neutral with regard to jurisdictional claims in published maps and institutional affiliations.

\section{Author details}

${ }^{1}$ Department of Clinical Pharmacy, College of Pharmacy, King Saud University, P.O. Box 2454, Riyadh 11451, Saudi Arabia. ${ }^{2}$ Department of Pharmaceutical Care, King Faisal Specialist Hospital and Research Center, Riyadh, Saudi Arabia. ${ }^{3}$ Department of Rehabilitation Sciences, College of Applied Medical Sciences, King Saudi University, Riyadh, Saudi Arabia. ${ }^{4}$ King Abdulaziz University Hospital, Riyadh, Saudi Arabia. ${ }^{5}$ Department of Medicinal Chemistry, College of Pharmacy, King Saud University, Riyadh, Saudi Arabia.

Received: 11 October 2017 Accepted: 26 April 2019

Published online: 14 May 2019

\section{References}

1. Woods M, Rosenberg ME. Educational tools: thinking outside the box. Clin J Am Soc Nephrol. 2016;11(3):518-26.

2. Mazur E. Farewell, lecture? Science. 2009;323(5910):50-1.

3. Prince M. Does active learning work? A review of the research. J Eng Educ. 2004;93(3):223-31

4. Michael J. Where's the evidence that active learning works? Adv Physiol Educ. 2006;30(4):159-67.

5. Gleason BL, Peeters MJ, Resman-Targoff BH, et al. An active-learning strategies primer for achieving ability-based educational outcomes. Am J Pharm Educ. 2011;75(9):186.

6. Marshall LL, Nykamp DL, Momary KM. Impact of abbreviated lecture with interactive mini-cases vs traditional lecture on student performance in the large classroom. Am J Pharm Educ. 2014;78(10):189.

7. Rotellar C, Cain J. Research, perspectives, and recommendations on implementing the flipped classroom. Am J Pharm Educ. 2016;80(2):34

8. Bleske $B E$, Remington $T L$, Wells $T D$, et al. A randomized crossover comparison of team-based learning and lecture format on learning outcomes. Am J Pharm Educ. 2016;80(7):120.

9. Freeman S, Eddy SL, McDonough M, et al. Active learning increases student performance in science, engineering, and mathematics. Proc Natl Acad Sci U S A. 2014;111(23):8410-5.

10. Accreditation Council for Pharmacy Education. Guidance for the accreditation standards and key elements for the professional program in pharmacy leading to the doctor of pharmacy degree. 2016. https://www. acpe-accredit.org/pdf/GuidanceforStandards2016FINAL.pdf. Accessed 20 Sept 2017.

11. Ramnanan CJ, Pound LD. Advances in medical education and practice: student perceptions of the flipped classroom. Adv Med Educ Pract. 2017:8: 63-73. 
12. Johnson DW, Johnson RT, Smith $\mathrm{K}$. The state of cooperative learning in postsecondary and professional settings. Educ Psychol Rev. 2007;19(1): $15-29$.

13. Earl GL. Using cooperative learning for a drug information assignment. Am J Pharm Educ. 2009;73(7):132.

14. Meo SA. Evaluating learning among undergraduate medical students in schools with traditional and problem-based curricula. Adv Physiol Educ. 2013;37(3):249-53.

15. Zahid MA, Varghese R, Mohammed AM, Ayed AK. Comparison of the problem based learning-driven with the traditional didactic-lecture-based curricula. Int J Med Educ. 2016;7:181-7.

16. Ofstad W, Brunner $\sqcup$. Team-based learning in pharmacy education. Am J Pharm Educ. 2013;77(4):70.

17. Bonwell CC. Active learning: creating excitement in the classroom. 2010 https://www.ydae.purdue.edu/lct/hbcu/documents/Active_Learning_ Creating_Excitement_in_the_Classroom.pdf. Accessed 20 Sept 2017.

18. Yusuff KB. Does self-reflection and peer-assessment improve Saudi pharmacy students' academic performance and metacognitive skills? Saudi Pharm J. 2015;23(3):266-75

19. Armbruster P, Patel M, Johnson E, Weiss M. Active learning and studentcentered pedagogy improve student attitudes and performance in introductory biology. CBE Life Sci Educ. 2009;8(3):203-13.

20. Accreditation Council for Pharmacy Education. Directory of programs with certification status following June 2016 actions of the Board of Directors. 2016. https://www.acpe-accredit.org/pdf/DirectoryCertifiedPrograms.pdf. Accessed 20 Sept 2017.

21. Gholami M, Moghadam PK, Mohammadipoor F, et al. Comparing the effects of problem-based learning and the traditional lecture method on critical thinking skills and metacognitive awareness in nursing students in a critical care nursing course. Nurse Educ Today. 2016;45:16-21.

22. Peterson RA, Kim Y. On the relationship between coefficient alpha and composite reliability. J Appl Psychol. 2013;98(1):194-8.

23. Wilberding E. Teach Like Socrates: Guiding Socratic Dialogues and Discussions in the Classroom. Waco: Prufrock Press; 2014.

24. Bonwell C, Eison JA. Active learning: creating excitement in the classroom. ASHE-ERIC Higher Education Reports 1991. http://files.eric.ed.gov/fulltext/ ED336049.pdf. Accessed 20 Sept 2017.

25. McKeachie WJ, Pintrich PR, Lin YG, Smith DA. Teaching and learning in the college classroom: A review of the literature. Ann Arbor: National Center for Research to Improve Postsecondary Teaching and Learning, The University of Michigan; 1987. http://files.eric.ed.gov/fulltext/ED314999.pdf. Accessed 20 Sept 2017

26. Rangachari PK. Back to the future? Active learning of medical physiology in the 1900s. Adv Physiol Educ. 2007;31:283-7.

27. Byrnes JP, Miller DC, Schafer WD. Gender differences in risk taking: a metaanalysis. Psychol Bull. 1999;125:367-83.

28. Harris $C R$, Jenkins M, Glaser D. Gender differences in risk assessment: why do women take fewer risks than men? Judgm Decis Mak. 2006;1(1):48-63.

29. Eagly AH, Johnson BT. Gender and leadership style: a meta-analysis. Psychol Bull. 1990;108:233-56.

30. Welsh AJ. Exploring undergraduates' perceptions of the use of active learning techniques in science lectures. J Coll Sci Teach. 2012;42(2):80-7.

31. Miller CJ, Metz MJ. A comparison of professional-level faculty and student perceptions of active learning: its current use, effectiveness, and barriers. Adv Physiol Educ. 2014;38(3):246-52.

32. Niemi H. Active learning - a cultural change needed in teacher education and schools. Teach Teach Educ. 2002;18:763-80.

33. North MS, Fiske ST. Modern attitudes toward older adults in the aging world: a cross-cultural meta-analysis. Psychol Bull. 2015;141(5):993-1021.

34. Miller CJ, McNear J, Metz MJ. A comparison of traditional and engaging lecture methods in a large, professional-level course. Adv Physiol Educ. 2013;37(4):347-55.

35. Al-Subaihi AA. Comparison of web and telephone survey response rates in Saudi Arabia. Electron J Bus Res Methods. 2008;6(2):123-32.

36. Saleh A, Bista K. Examining factors impacting online survey response rates in educational research: perceptions of graduate students. J MultiDisciplinary Eval. 2017;13(29):63-74.

37. Yetter G, Capaccioli K. Differences in responses to web and paper surveys among school professionals. Behav Res Methods. 2010;42(1):266-72.
38. Harzing AW, Reiche BS, Pudelko M. Challenges in international survey research: a review with illustrations and suggested solutions for best practice. Eur J Int Manag. 2013;7(1):112-34.

39. Choi NG, DiNitto DM. Internet use among older adults: association with health needs, psychological capital, and social capital. J Med Internet Res. 2013;15(5):e97.

\section{Ready to submit your research? Choose BMC and benefit from:}

- fast, convenient online submission

- thorough peer review by experienced researchers in your field

- rapid publication on acceptance

- support for research data, including large and complex data types

- gold Open Access which fosters wider collaboration and increased citations

- maximum visibility for your research: over $100 \mathrm{M}$ website views per year

At $\mathrm{BMC}$, research is always in progress.

Learn more biomedcentral.com/submissions 